KOMUNIKASI RINGKAS

\title{
PENGARUH VITAMIN A DALAM PAKAN TERHADAP PERKEMBANGAN GONAD INDUK UDANG WINDU (Penaeus monodon) ASAL TAMBAK
}

\author{
Nyoman Adiasmara Giri", Muhamad Marzuqi", Samuel Lante*, Ketut Suwirya", \\ dan Seiichi Tsumura"*)
}

\begin{abstract}
ABSTRAK
Percobaan ini dilakukan untuk mengetahui pengaruh dan kebutuhan vitamin A dalam pakan untuk pematangan gonad udang windu asal tambak. Induk udang windu betina dengan bobot rata-rata $85,15 \pm 7,62 \mathrm{~g}$ dan jantan 60,40 $\pm 5,78 \mathrm{~g}$ dipelihara dalam bak beton volume 16 $\mathrm{m}^{3}$ dengan kepadatan 20 pasang per bak dan diberikan pakan buatan yang mengandung kadar vitamin A yang berbeda, yaitu 0,00\%; 0,01\%;0,02\%; dan 0,03\%. Induk udang diberi pakan percobaan selama 48 hari. Untuk menguji respon pakan terhadap perkembangan gonad, pada hari ke-32 semua induk betina diablasi dengan memotong sebelah tangkai matanya. Hasil pengamatan menunjukkan bahwa penambahan vitamin A dalam pakan menghasilkan sintasan yang lebih tinggi dibandingkan dengan kontrol untuk induk udang betina, tetapi tidak untuk induk jantan. Kandungan vitamin A dalam gonad meningkat dengan meningkatnya kandungan vitamin A dalam pakan. Penambahan vitamin A 0,02 dan 0,03\% dalam pakan meningkatkan nilai indeks gonad somatik (IGS) serta meningkatkan dan mempercepat kematangan gonad induk udang betina.
\end{abstract}

ABSTRACT: Effect of dietary vitamin $A$ on gonadal maturation of pond reared tiger prawn, Penaeus monodon. By: Nyoman Adiasmara Giri, Muhamad Marzuqi, Samuel Lante, Ketut Suwirya, and Seiichi Tsumura.

A feeding experiment was carried out to examine the effect and requirement of vitamin A for gonadal maturation of pond-reared tiger prawn, Penaeus monodon. Prawn with average body weight of $85.15 \pm 7.62 \mathrm{~g}$ for female and $60.40 \pm 5.78 \mathrm{~g}$ for male, respectively, were fed diets containing different levels of vitamin A palmitate $(0.00 \% ; 0.01 \%: 0.02 \%$; and $0.03 \%$ dry weight) for 48 days. To evaluate the effect of dietary vitamin A on gonadal maturation, all females were eyestalk ablated on day-32. The results of the experiment showed that supplementation of vitamin A in experimental diets resulted in higher survival compared to control for female prawn, but not for males. Vitamin A content in the gonad of prawns fed with (?????) experimental diets increased with increasing dietary vitamin A level. Supplementation of vitamin A at levels of 0.02 and $0.03 \%$ in the experimental diets improved gonadal maturation of female prawn and gonado somatic index (GSI) values.

KEYWORDS: Penaeus monodon, gonadal maturation, Vitamin A.

\section{PENDAHULUAN}

Peningkatan produksi benih udang sangat tergantung pada mutu induk, dan untuk mendapatkan mutu induk dan larva udang yang baik dapat dilakukan melalui perbaikan mutu pakan, lingkungan, dan genetik. Seperti hewan lainnya, secara umum kebutuhan nutrien udang meliputi protein, karbohidrat, lemak, vitamin, dan mineral (NRC, 1981). Rothlisberg et al. (1991) melaporkan bahwa kandungan nutrien pakan induk berpengaruh nyata terhadap kematangan gonad dan pemijahan Penaeus esculentus.
Watanabe (1985) menekankan pentingnya faktor nutrisi untuk induk dalam pengembangan budi daya perikanan. Vitamin dalam pakan memainkan peranan yang penting dalam fungsi fisiologis, termasuk dalam proses reproduksi (Sandnes et al., 1984; Soliman et al., 1986; Shim \& Tan, 1989; Primavera, 1985).

Akhir-akhir ini beberapa peneliti telah memfokuskan penelitiannya mengenai pengaruh vitamin untuk memacu perkembangan gonad dan pemijahan udang, di antaranya pengaruh vitamin C (Alava et al., 1993a; 1993b; Marzuqi et al. Inpress), Vitamin E (Alava et al., 1993b; Cahu et

Peneliti pada Loka Penelitian Perikanan Pantai Gondol 
al., 1991: Marzuqi et al., 1996), dan vitamin A (Alava et al., 1993b). Namun demikian informasi mengenai kebutuhan vitamin yang diduga berperan penting dalam memacu proses perkem. bangan gonad, pemijahan, meningkatkan kualitas telur dan larva udang masih terbatas. Cahu et al. (1991) melaporkan penambahan vitamin $\mathrm{E}$ acetat $600 \mathrm{mg} / 100 \mathrm{~g}$ pakan berpengaruh nyata terhadap peningkatan daya tetas telur Penaeus indicus dan 90\% larva yang dihasillkan berkualitas baik. Alava et al. (1993b) melaporkan bahwa vitamin A dalam pakan adalah esensial untuk meningkatkan perkembangan ovari udang $P$. japonicus, namun mekanisme dan kebutuhan vitamin A yang tepat belum diketahui. Bertitik tolak pada permasalahan tersebut di atas maka dilakukan penelitian yang bertujuan untuk mempelajari pengaruh vitamin $A$ dalam pakan terhadap perkembangan gonad udang windu.

\section{BAHAN DAN METODE}

Pada penelitian ini digunakan pakan dalam bentuk pelet dengan komposisi seperti tertera pada Tabel 1. Pada setiap pakan ditambahkan vitamin A palmitat dengan kadar yang berbeda yaitu $0.00 \% ; 0,(01 \% ; 0,02 \%$; dan $0.03 \%$

Hewan uji berupa udang windu dengan bobot rata-rata $85,15 \pm 7,62 \mathrm{~g}$ untuk betina dan $60,40 \pm$ 5,78 g untuk jantan diperoleh dari hasil pemeliharaan di instalasi tambak percobaan Loka Penelitian Perikanan Pantai di Pejarakan. Buleleng-Bali. Induk udang diadaptasikan selama seminggu dalam bak pemeliharaan sebelum diberikan pakan percobaan. Wadah percobaan yang digunakan adalah empat bak beton bervolume $16 \mathrm{~m}$ " dengan sistem double bottom dan dilengkapi dengan aerasi. Masing-masing bak diisi 20 pasang induk udang dengan perbandingan betina dan jantan 1:1. Untuk

Tabel 1. Komposisi pakan percobaan.

Table 1. The composition of experimental diets.

\begin{tabular}{|c|c|c|c|c|}
\hline \multirow{2}{*}{$\begin{array}{l}\text { Bahan Pakan } \\
\text { Ingredient }\end{array}$} & \multicolumn{4}{|c|}{$\begin{array}{c}\text { Kadar vitamin A dalam pakan }(\%) \\
\text { Dietary vitamin A level ( }(\%)\end{array}$} \\
\hline & 0.00 & 0.01 & 0.02 & 0.03 \\
\hline Kasein (Casein) & 25.00 & 25.00 & 25.00 & 25.00 \\
\hline Tepung ikan (Fish meal) & 37.00 & 37.00 & 37.00 & 37.00 \\
\hline Tepung cumi (Squid meal) & 9.48 & 9.48 & 9.48 & 9.18 \\
\hline Minyak sardin (Sardine oil) & 4.00 & 4.00 & 4.00 & 4.00 \\
\hline Minyak hati cumi (Squid liver oil) & 2.00 & 2.00 & 2.00 & 2.00 \\
\hline Lesitin (Lecithin) & 3.00 & 3.00 & 3.00 & 3.00 \\
\hline Campuran vitamin (Vitamin mix*) & 3.44 & 3.44 & 3.44 & 3.14 \\
\hline Campuran mineral (Mineral mix**) & 6.00 & 6.00 & 6.00 & 6.00 \\
\hline Kolesterol (Cholesterol) & 0.50 & 0.50 & 0.50 & 0.50 \\
\hline Arginin-HCl & 1.00 & 1.00 & 1.00 & 1.0() \\
\hline Vitamin $A$-palmitat & 0.00 & 0.01 & 0.02 & $0.0 ; 3$ \\
\hline Solulose (Cellulose) & 0.58 & 0.57 & 0.56 & $(0.55$ \\
\hline Kanji (Cassava meal) & 3.00 & 3.00 & 3.00 & 3.00 \\
\hline Terigu (Wheat flour) & 5.00 & 5.00 & 5.00 & 5.0() \\
\hline \multicolumn{5}{|l|}{ Hasil Analisis (Analy'sis): } \\
\hline Vitamin $A(\mathrm{mg} / \mathrm{g})$ & 0.03 & 0.11 & 0.20 & $(0.28$ \\
\hline Protein (Crude protein, \%) & 56.64 & 55.79 & 55.24 & 5.5 .99 \\
\hline Lemak total (Total lipid. (n) & 11.55 & 10.38 & 10.09 & 10.02 \\
\hline NFE $(\%)$ & 18.10 & 21.21 & 21.57 & 20.54 \\
\hline
\end{tabular}

* Vitamin mix (mg/lo()g pakan): p-aminobenzoic acid 15.80; Biotine 0.633; Inositol (332.0(): Niarin (33.20: Cal-panthotenate 94.80: Pyridoxine 18.96: Ribotlavin 12.64: Thiamine (5.32: Folie acid 1.2(i: Cyanorobalamin (0.13: Choline chloride 948.00): Vitamin C PMg 136.00: Menadion 6.3.t: Vitamin E 1500) (calciferol 1.90 .

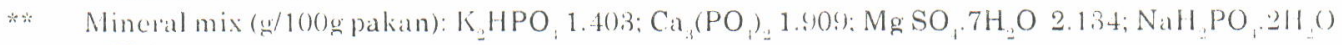
0.5 .54 
memonitor pertumbuhan, sintasan, tingkat kematangan gonad dan pemijahan seraca individu, maka setiap individu betina diberi tanda atau nomor dengan karet berlubang pada tangkai matanya. Induk udang dipelihara dengan sistem air mengalir dengan pergantian air mencapai $125 \%$ per hari.

Pakan percobaan diberikan pada pagi dan sore hari sebanyak 3\% dari bobot biomassa. Sisa pakan dan kotoran dibersihkan pada setiap pagi hari. Untuk mengetahui respon dari masing-masing perlakuan, maka setelah dipelihara dengan pakan percobaan selama 32 hari, di mana kondisi udang telah dipengaruhi oleh pakan perlakuan, semua induk betina diablasi satu tangkai matanya. Selanjutnya perkembangan gonad diamati setiap hari (Lampiran 1). Induk matang gonad (tingkat III) dipindahkan ke dalam bak pemijahan. Pada akhir percobaan ( 16 hari setelah ablasi) dilakukan pembedahan guna mendapatkan bobot gonad dan hepatopankreas untuk menentukan indeks gonad somatik (IGS=bobot gonad x 100\%/bobot tubuh) dan indeks hepato somatik (IHS = bobot hepatopankreas x 100\% per bobot tubuh). Gonad dan hepatopankreas masing-masing perlakuan dikumpulkan dan disimpan pada suhu $-20^{\circ} \mathrm{C}$ untuk dianalisis kandungan vitamin A nya. Kandungan vitamin A dalam pakan, gonad, dan hepatopankreas dianalisis dengan High Performance Liquid Chromatography (HPLC) menurut metode yang dilaporkan Alava et al. (1993b).

\section{HASIL DAN BAHASAN}

Hasil pengamatan terhadap sintasan, IGS dan IHS induk udang betina yang diberi pakan dengan kadar vitamin A yang berbeda tertera pada Tabel 2. Induk udang yang diberi pakan tanpa penambahan vitamin A mengalami banyak kematian baik sebelum maupun sesudah dilakukan ablasi. Sementara pada udang yang diberi pakan dengan penambahan vitamin A terjadi sintasan yang lebih tinggi. Gejala ini tidak terlihat pada induk udang jantan (Tabel 3) di mana sintasan udang yang diberi pakan tanpa jenambahan vitamin A juga tinggi. Indeks gonad somatik (IGS) rata-rata lebih tinggi pada udang yang diberi pakan dengan penambahan 0,02 dan 0,03\% vitamin A (Tabel 2 ). Hal yang sama juga diamati pada P. japonicus (Alava et al., 1993b). Ini menunjukkan bahwa vitamin $\mathrm{A}$ dibutuhkan pada proses perkembangan gonad. Fisher \& Kon (1958) melajorkan bahwa krustase menyimpan vitamin A selama proses pematangan gonad, yang mana selanjutnya ditransfer ke oosit. Mekanisme kerja dari retinol (bentuk aktif dari vitamin $\mathrm{A}$ ) sangat mirip dengan hormon steroid dan tiroksin yang tercakup pada proses aktivasi dari ekspresi gen spesifik dan menempatkan retenoid dalam kategori hormon yang mengontrol pertumbuhan, diferensiasi, dan perkembangan embrio (Wolf, 1990). Selanjutnya Fisher (1960) melaporkan di atas $90 \%$ vitamin A pada krustase dikonsentrasikan dalam mata.

Pada percobaan ini kandungan vitamin A pada gonad dan hepatopankreas mengalami peningkatan dengan meningkatnya kadar vitamin $\mathrm{A}$ dalam pakan. Menurunnya kandungan vitamin A pada gonad dan hepatopankreas udang yang diberi pakan dengan penambahan 0,01\% atau kurang vitamin A dalam pakan menunjukkan bahwa cadangan vitamin A pada hepatopankreas di-

Tabel 2. Sintasan, indek gonad somatik (IGS), dan indek hepatosomatik (IHS) udang betina pada akhir percobaan.

Table 2. Survival, gonadosomatic index (GSI), and hepatosomatic index (HSI) of female prawn at the end of experiment.

\begin{tabular}{|c|c|c|c|c|c|}
\hline \multirow{2}{*}{$\begin{array}{c}\text { Kadar vit. A } \\
\text { dalam pakan } \\
\text { Dietary vit A level } \\
(\%)\end{array}$} & \multirow{2}{*}{$\begin{array}{c}\text { Sintasan } \\
\text { Survival } \\
(\%)\end{array}$} & \multirow{2}{*}{ GSI } & \multirow{2}{*}{ HSI } & \multicolumn{2}{|c|}{$\begin{array}{l}\text { Kand ungan vit A }(\mu \mathrm{g} / \mathrm{g}) \\
\text { Vit } A \text { content }(\mu \mathrm{g} / \mathrm{g})\end{array}$} \\
\hline & & & & Gonad & $\begin{array}{l}\text { Hepatopankreas } \\
\text { Hepatopancreas }\end{array}$ \\
\hline 0.00 & 26.3 & $1.07 \pm 0.26$ & $2.61 \pm 0.57$ & 0.88 & 4.13 \\
\hline 0.01 & 52.6 & $0.79 \pm 0.23$ & $2.31 \pm 0.54$ & 0.97 & 5.05 \\
\hline 0.02 & 47.4 & $1.31 \pm 0.77$ & $2.54 \pm 0.46$ & 1.90 & 7.96 \\
\hline 0.03 & 42.1 & $1.43 \pm 1.52$ & $2.49 \pm 1.59$ & 2.59 & 8.27 \\
\hline
\end{tabular}

*Initial : Gonad $=1.47 \mu \mathrm{g} / \mathrm{g} ;$ hepatopancreas $=2.72 \mu \mathrm{g} / \mathrm{g}$ 
Tabel 3. Sintasan dan indek hepato somatik (IHS) udang jantan pada akhir percobaan.

Table 3. Survival and hepatosomatic index (HSI) of male prawn at the end of the experimenl.

\begin{tabular}{ccc}
\hline $\begin{array}{c}\text { Kadar vit. A dalam pakan } \\
\text { Dietary vit A level } \\
(\%)\end{array}$ & $\begin{array}{c}\text { Sintasan } \\
\text { Sulvival } \\
(\%)\end{array}$ & HSI \\
\hline 0.00 & 63.2 & $3.00 \pm 0.32$ \\
0.01 & 36.8 & $2.96 \pm 0.54$ \\
0.02 & 63.2 & $2.83 \pm 0.84$ \\
0.03 & 63.2 & $2.74 \pm 0.12$ \\
\hline
\end{tabular}

metabolisme untuk memenuhi kebutuhannya. Sedangkan kelebihan vitamin A dapat disimpan pada hepatopankreas yang terlihat dengan meningkatnya kandungan vitamin A pada hepatopankreas udang yang diberi pakan dengan penambahan $0.02 \%$ dan $0,03 \%$ vitamin $\mathrm{A}$ dalam pakannya. Kelebihan vitamin A pada ikan dan hewan lainnya dapat mengakibatkan pembesaran hati, pertumbuhan yang tidak normal, kerusakan pada kulit. dan pembentukan tulang yang tidak normal (Halver, 1989). Namun pada percobaan ini tidak terlihat adanya pengaruh negatif dari kelebihan vitamin A. Dengan memperhatikan kandungan vitamin A pada awal percobaan $(1,47$ $\mathrm{mg} / \mathrm{g}$ gonad) dan nilai IGS, maka untuk mempertahankan proses perkembangan gonad diperlukan penambahan vitamin A $0,02-0,03 \%$ dalam pakan. Lebih lanjut pada Tabel 4 terlihat bahwa hanya udang yang diberi pakan dengan ablasi. Pemijahan pertama pada udang vang diburi pakan dengan penambahan $0.02 \%$ vitamin $A$ terjadi pada hari ke-39 setelah diberi pakan percobaan. Namun jumlah telur yang clihasilkan hanya 132.178 butir dengan kualitas yang kurang baik. Walaupun pengamatan di bawah mikroskop menunjukkan bahwa telur dibuahi. namun perkembangan pembelahan telur ini terhenti dan telur tidak menetas. Sementara induk lainnya pada kelompok perlakuan ini yang juga mencapai tingkat kematangan gonad lanjut tidak memijah dan telur diabsorbsi kembali. Terhentinya perkembangan telur mungkin dikarenakan kualitas telur yang kurang baik di mana tidak tersedia cukup cadangan energi untuk mondukung proses perkembangan selanjutnya. Demikian juga dengan induk yang tidak memijah dan gonadnya diserap kembali. Hal ini juga mungkin rerkait dengan kualitas induk tambak yang kurang baik.

'Tabel 4. Jumlah induk udang betina matang gonad, memijah, dan jumlah telur yang dihasilkan setelah ablasi.

Table 4. Number of prawn reached maturation slage, spawning, and eggs produced after ablation.

\begin{tabular}{|c|c|c|c|c|c|}
\hline \multirow{2}{*}{$\begin{array}{c}\text { Kadar vit A } \\
\text { dalam pakan } \\
\text { Dietary vit. A } \\
\text { level } \\
(\%)\end{array}$} & \multicolumn{3}{|c|}{$\begin{array}{l}\text { Tingkat matang gonad } \\
\text { Maturation stage }\end{array}$} & \multirow{2}{*}{$\begin{array}{l}\text { Memijah } \\
\text { Spawning }\end{array}$} & \multirow{2}{*}{$\begin{array}{l}\text { Jumlah } \\
\text { telur } \\
\text { Eggs } \\
\text { produced }\end{array}$} \\
\hline & I & II & III & & \\
\hline 0.00 & - & & - & & \\
\hline 0.01 & - & - & & - & \\
\hline 0.02 & i3 & 2 & 2 & 1 & 132.175 \\
\hline 0.0 .3 & 1 & 1 & 1 & $2^{*}$ & 221,661 \\
\hline
\end{tabular}

"Hanya satu induk memijah dua kali (Om/y one female spenched two times)

penambahan 0.02 dan $0.03 \%$ vitamin $\mathrm{A}$ yang menunjukkan adanya perkembangan gonad sampai mencapai pemijahan setelah dilakukan
Alava et al. (1993b) melaporkan bahwa tingkat kematangan gonad udang $P$. japonicus diperoleh 
setelah pemeliharaan selama 57 hari dalam bakbak percobaan. Dilaporkan pula bahwa vitamin A merupakan nutrien pakan yang penting untuk perkembangan gonad $P$. japonicus. Penambahan vitamin A palmitat sebanyak $15 \mathrm{mg} / 100 \mathrm{~g}$ pakan positif meningkatkan IGS dari $P$. japonicus yang diablasi.

Pada kelompok udang yang diberi pakan dengan penambahan $0.03 \%$ vitamin $\mathrm{A}$ hanya satu ekor udang yang mencapai kematangan gonad. Namun udang ini menunjukkan kematangan gonad yang berulang, yaitu pemijahan pertama

\section{KESIMPULAN}

1. Penambahan vitamin A dapat menekan tingkat kematian induk udang yang diablasi tetapi tidak berpengaruh terhadap induk jantan.

2. Untuk memacu perkembangan gonad induk udang windu asal tambak dibutuhkan pe. nambahan $0,02 \%$ vitamin A dalam pakannya.

3. Gonad yang tidak memijah dan sperma yang tidak normal dalam percobaan ini belum diketahui apakan sebagai efek samping vitamin $\mathrm{A}$ atau pengaruh lingkungan tambak.

Tabel 5. Kualitas air selama percobaan.

Table 5. Water quality during the experiment.

\begin{tabular}{lcccc}
\hline $\begin{array}{c}\text { Peubah } \\
\text { Parameter }\end{array}$ & \multicolumn{3}{c}{$\begin{array}{c}\text { Kadar vit A dalam pakan (\%) } \\
\text { Dietary vit. A level (\%) }\end{array}$} \\
\cline { 2 - 5 } & 0.00 & 0.01 & 0.02 & 0.03 \\
\hline Suhu (Temperature, oC) & $29.6-30.7$ & $29.6-30.5$ & $29.6-30.5$ & $29.6-30.5$ \\
Salinitas (Salinity, ppt) & $32-34$ & $32-34$ & $32-34$ & $32-34$ \\
pH & $7.89-8.04$ & $7.84-8.03$ & $7.85-8.03$ & $7.85-8.03$ \\
Oksigen terlarut (Dissolved & $5.32-5.40$ & $5.48-5.64$ & $5.36-5.77$ & $5.34-5.63$ \\
oxygen, mg/L) & & & & \\
\hline
\end{tabular}

dan ke dua terjadi berturut-turut pada hari ke-40 dan hari ke-44 dengan jumlah telur yang dihasilkan mencapai 123.499 dan 101.165 butir. Telur ini juga dibuahi, namun perkembangan pembelahannya terhenti dan telur tidak menetas.

Melihat perkembangan telur yang terhenti pada kedua kelompok perlakuan (0,02 dan 0,03\% vitamin A) diduga bahwa kualitas induk jantannya juga kurang baik. Dari pengamatan sperma induk jantan terlihat bahwa jumlah dan persentase ketidaknormalannya sangat bervariasi untuk semua kelompok perlakuan. Tingkat ketidak normalan sperma rata-rata mencapai 42,8-51,9\% dan terlihat tidak dipengaruhi oleh perbedaan kadar vitamin A dalam pakan. Tingginya persentase sperma tidak normal induk jantan asal tambak dapat disebabkan oleh kondisi lingkungan tambak yang kurang baik serta manajemen selama pemeliharaan di tambak yang mungkin masih menggunakan beberapa bahan kimia.

Pengamatan terhadap beberapa peubah kualitas air yang meliputi suhu, pH, salinitas, oksigen terlarut selama percobaan masih menunjukkan kisaran yang layak untuk pemeliharaan induk udang windu (Tabel 5).

\section{DAFTAR PUSTAKA}

Alava, V.R., Kanazawa, A., Teshima, S. and Koshio, S. 1993a. Effect of dietary L-ascorbyl 2-phosphate Magnesium on gonadal maturation of Penaeus japonicus. Bull Jap. Soc. Sci. Fish. 59(4): 691-786.

Alava, V.R., Kanazawa, A., Teshima, S. and Koshio, S. 1993b. Effect dietary vitamin A, E and C on ovarian development of Penaeus japonicus. Bull. Jap. Soc. Sci. Fish. 59 (7): 1235-1241.

Cahu, C., Fakhfakh, M. and Quazuguel, P. 1991. Effect of dietary a-tocopherol level on reproduction of Penaeus indicus. In Lavens, P., Sorgeloos, P., Jaspers, E. and Ollevier, F. (Eds.), Larvi'91 Fish \& Crustacean Larviculture Symposium. Special Publ. No. 15. European Aquaculture Society. Ghent, Belgium. 242.244

Fisher, L.R. and Kon. S.K. 1958. Vitamin A in the invertebrates. Biol. Rev., 34: 1-24

Fisher, L. R. 1960. Vitamins. In Waterma, Y.H. (Ed.). Physiology of Crustacea, Vol 1. Academic Press, New York. 259-289

Marzuqi, M.. Suwirya, K. dan Tsumura, T. 1996. Pengaruh vitamin E terhadap perkembangan gonad udang windu (P. monodon) asal tambak. J. Penelit. Perikan. Indones. Vol II (2):1-5. 
Marzuqi. M.. Suwirya. K. dan Azwar, Z.I. 1997. Pengaruh askorbil fosfat magnesium sebagai sumber vitamin $\mathrm{C}$ terhadap pematangan gonad udang windu, Penaeus monodon asal tambak. J. Penelit. Perikan. Indones. (3) 3: 41-46

NRC. 1981. Nutrient Requirement of Cold Water Fishes. National Academic Sciences Press. Washington. D.C. USA. 63 pp.

Primavera. J.H. 1985. A review of maturation and reproduction in closed thelycum penaeid. In Taki. Y. Primavera. J.H. and Llobrere. J.A. (Eds.). Proceeding First. Inter. Conf. Cult. Penasid Prawns/ Shrimps. Ho-Ho, Philippines. $17-61$.

Rothlisberg, P.C.. Crocos, P.J. and Smith, D.M. 1991. The effect of diet and eyestalk ablation on maturation, spawning. hatching, and larval fitness of Penaeus esculentus. In Lavens, P.. Sorgeloos. P., Jaspers, E. and Ollevier, F. (Eds.), Larvi '91 Fish \& Crustarean Larviculture Symposium. Special Publ. No. 15. European Aquaculture Society. Ghent. Belgium. 247.250

Sandnes. K.. Ulgenes, Y.. Braekkan, O.R. and Utne, F. 1984. The effect of ascorbic acid supplementation in broodstock feed on reproduction of rainbow troul (Salmo gairdineri). Aquaculture, 43: 167-177

Shim, K.F. and Tan, C.H. 1989. The dietary requirement of vitamin $\mathrm{A}$ in guppy (Porcilic reticulata Peters). In Takeda, M. and Watanabe. T. (Eds.), Proceeding Third Int. Symp. on Feeding and Nutr. in Fish. August 28- Sept 1. 1989. Toba. Japan. 133-140

Soliman. A.. Jauncey. K.K. and Roberts. R.J. 1986. The effect of dietary ascorbic acid supplementation of hatchability, survival rate and fry performance on Oreochromis mossambicus (Peters). Acuaculture. 59: $197-208$.

Watanabe. T. 1985. Importance of the study of broodstock nutrition for further development of aquaculture. In Cowey, C.B., Mackie, A.M. and Bell. J.G. (Eds.), Nutrition and Feeding in Fish. Academic Press, London. 395-414

Wofl, G. 1990. Recent progress in vitamin A resench nucleas retinoic acid receptors and their interaction with gene elements. J. Nutr. Biorhem. 1: $28+289$ 
Iampiran 1. Data pengamatan perkembangan gonad udang setelah diablasi. Appendix 1. Gonadal development after ablation of female prawn.

\begin{tabular}{|c|c|c|c|c|c|}
\hline \multirow{2}{*}{$\begin{array}{c}\text { Hari setelah } \\
\text { abalasi Ablasi } \\
\text { Day after ablation }\end{array}$} & \multirow{2}{*}{$\begin{array}{c}\text { Tingkat } \\
\text { kematangan gonad } \\
\text { Gonad stage }\end{array}$} & \multicolumn{4}{|c|}{$\begin{array}{c}\text { Kadar vit A dalam pakan (\%) } \\
\text { Dietary vit A level }(\%)\end{array}$} \\
\hline & & 0.00 & 0.01 & 0.02 & 0.03 \\
\hline \multirow[t]{3}{*}{5} & I & - & $\cdot$ & 1 & 1 \\
\hline & II & - & - & 1 & . \\
\hline & III & . & - & . & . \\
\hline \multirow[t]{3}{*}{6} & I & - & - & - & . \\
\hline & II & - & - & 1 & 1 \\
\hline & III & - & - & 2 & - \\
\hline \multirow[t]{3}{*}{7} & I & - & - & - & - \\
\hline & II & - & - & 1 & 1 \\
\hline & III & - & - & $\begin{array}{l}1 \text { memijah } \\
\text { (1 spawned) }\end{array}$ & . \\
\hline \multirow[t]{3}{*}{8} & I & . & - & - & - \\
\hline & II & . & - & 2 & - \\
\hline & III & . & - & - & $\begin{array}{l}1 \text { memijah } \\
(1 \text { spawned) }\end{array}$ \\
\hline \multirow[t]{3}{*}{4} & I & - & - & - & - \\
\hline & II & - & . & . & . \\
\hline & III & . & - & 2 & - \\
\hline \multirow[t]{3}{*}{10} & I & - & - & . & - \\
\hline & II & - & - & - & 1 \\
\hline & III & . & . & 2 & . \\
\hline \multirow[t]{3}{*}{11} & I & . & . & - & \\
\hline & II & . & - & - & \\
\hline & III & - & . & $\begin{array}{l}1 \text { diserap } \\
(1 \text { absorbed })\end{array}$ & $\begin{array}{c}1 \text { parsial } \\
(1 \text { partially })\end{array}$ \\
\hline \multirow[t]{3}{*}{12} & I & - & - & - & . \\
\hline & II & - & - & 1 & 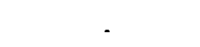 \\
\hline & III & - & - & 1 & $\begin{array}{l}1 \text { memijah } \\
(1 \text { spawned })\end{array}$ \\
\hline \multirow[t]{3}{*}{1.3} & I & . & . & - & + \\
\hline & II & . & - & 1 & - \\
\hline & III & - & - & $\begin{array}{c}1 \text { diserap } \\
(1 \text { absorbed })\end{array}$ & - \\
\hline \multirow[t]{3}{*}{1.4} & I & . & - & - & - \\
\hline & II & . & - & 1 & 1 \\
\hline & III & - & - & - & - \\
\hline \multirow[t]{3}{*}{ iin } & 1 & . & - & - & . \\
\hline & II & - & . & 1 & 1 \\
\hline & III & - & - & - & . \\
\hline
\end{tabular}

\footnotetext{
Catatan (Noto):
}

1 memijah ( 1 spauned): 1 ekor induk betina dalam bak percobaan mengeluarkan telur (one female in the tante can produced eggs).

I parsial ( $/$ partially'): I okor udang perkembang gonadnya tidak sempurna, terputus-putus dan tidak terjadi pemijahan (one spawner partial, decelopment of gonad in on spawner was not properly, the gonad has segment, and did not spatoning).

1 diserap ( 1 absorbed): 1 ekor induk udang gonad berkembang sempurna pada awalnya, tetapi tidak berhasil memijah dan gonad mengecil kembali (in the beginning gonad in one spauner can developed, but it ran not spawning and the gonad for longer rearing was reduced). 